\title{
Springshed Mapping in Support of Watershed Management
}

\author{
Jeffrey A. Green ${ }^{1}$, Scott C. Alexander ${ }^{2}$ and E. Calvin Alexander, Jr. ${ }^{2}$
}

\begin{abstract}
Fillmore County has been the focal point of dye tracing efforts in Minnesota for several decades. In 1995, a 1:100,000, county-scale springshed map was published. At the county scale, we primarily delineated springsheds greater than 500 hectares. After that project was completed, dye-tracing efforts continued and focused on the South Branch Root River (SBRR) springshed in the western part of the county. At the scale of the SBRR springshed (about $20 \%$ of the county), we expanded the boundaries of the large springsheds but also located and refined the boundaries of springsheds that are less than 200 hectares. We found one previously unmapped small springshed (Meyers springshed), documented complex flow boundaries between a large springshed (11. Canfield) and an adjacent small springshed (26. Rainy), and expanded the boundaries of four other springsheds. The small springsheds present a new opportunity for karst watershed research, monitoring and management. The small springsheds are often dominated by one or a few land uses, which permit simpler, more evident identification of the causes of water quality
\end{abstract} degradation.

\section{Introduction}

The SBRR watershed in southeastern Minnesota contains many springsheds (karst groundwater springsheds). The SBRR rises as a warm water stream, sinks at Mystery Cave and then resurges as a coldwater stream that flows through Forestville State Park, and ultimately empties into the Mississippi River. Figure 1 shows the upper part of the watershed above Forestville State Park. The Minnesota Department of Natural Resources, Division of Waters published a springsheds map as part of the Fillmore County Geologic Atlas (Alexander et al., 1995). The 1995 map compiled two decades of tracing results with about 80 new traces to delineate allogenic and autogenic springsheds that were mapped at a 1:100,000 scale. The SBRR watershed contains a significant portion of the springsheds mapped in Fillmore County. The goal of the mapping was to provide a product to aid watershed managers, state

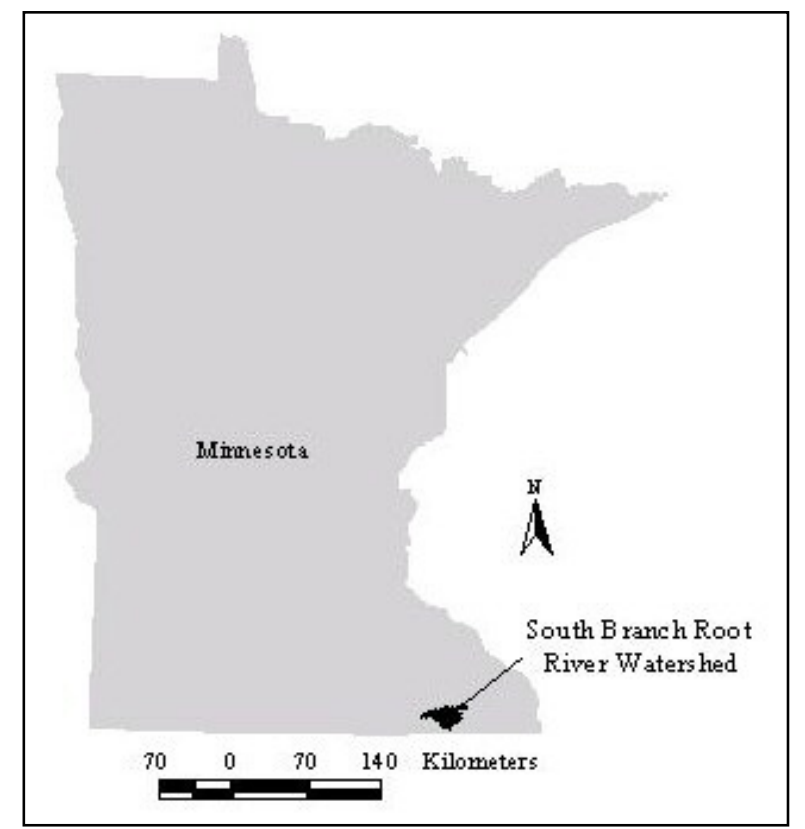

Figure 1. Location map of the upper SBRR watershed.

\footnotetext{
${ }^{1}$ Minnesota Department of Natural Resources, Division of Waters, 2300 Silver Creek Road NE, Rochester, MN 55906; PH (507) 285-7430; FAX (507) 285-7144; email: jeff.green@dnr.state.mn.us

${ }^{2}$ Geology \& Geophysics Department, University of Minnesota, 310 Pillsbury Dr. SE., Minneapolis, MN 55455; PH (612) 624-3517; FAX (612) 625-3819; emails: alexa017@umn.edu \& alexa001@umn.edu
} 
and local agencies and emergency responders as they dealt with karst water management issues.

The 1995 map, while useful, was not complete. To refine and expand the coverage of that map, a continuing program of dye traces has been conducted since 1995. The studies built on the 1995 map and extended the tracing to several sinkhole areas and significant stream sinks that had not been traced during the geologic atlas project. Since 1996 we have completed about twenty-four more traces to refine the existing springshed boundaries and delineate unmapped springsheds. Beginning in 1997, much of the tracing was funded through a series of Clean Water Partnership/US-EPA 319 projects in the upper end of the South Branch Root River watershed down through Forestville State Park. These new results are presented as a "Springsheds of Forestville" map (Green et al., 2005).

\section{Methods}

The traces reported here primarily utilized the fluorescent dyes uranine C (Color Index \# 45350, Chem. Abs. \# 518-47-8), eosin Y (Color Index \# 45380, Chem. Abs. \# 17372-87-1) and Rhodamine WT (Acid Red 388, Chem. Abs.\# 37299-86-8). Of the twenty-four traces, sixteen were flushed into dry sinkholes with 4,000 to 5,000 liters of water. Eight of the traces were done using snowmelt runoff. Runoff volumes varied from 1 to 1000 liters per minute depending on the depth of snow cover and the size of the watershed that was feeding runoff to the sinkhole or sinking stream. Both direct water samples and charcoal detectors were utilized to monitor appropriate springs in the SBRR watershed. Dye concentrations at the springs generally peaked in the $0.5-10 \mathrm{ppb}$ range. The charcoal detectors were eluted. The eluent was prepared by adding $\sim 10 \mathrm{~g}$ of $\mathrm{NaOH}$ (CAS 1310-73-2) to one liter batches 70\% 2-propanol (CAS 67-63-0) and $30 \%$ deionized water in a separatory funnel. A dense phase separated and was discarded. The lighter phase was the eluent. The eluent was analyzed in the laboratory along with the water samples using a scanning spectrofluorophotometer. The resulting emission spectra were recorded digitally and analyzed using the techniques described elsewhere in this volume by Alexander (2005). The results of these traces are discussed below.

\section{Results}

Four new small springsheds were mapped. The newly mapped small springsheds are about an order of magnitude smaller than the springsheds mapped by Alexander et al. (1995) and offer interesting possibilities for research. The large springsheds typically include much more complex land uses than do the small springsheds. A group of small springsheds with varied dominant land uses will be very useful to discriminate between the impacts of the different surface land uses. For example, most of the Meyers springshed is under a single farm. That farm is not in row crop agriculture. The other three small springsheds include significant corn and soybean production. A comparison of the water quality in these small springsheds, in theory, can separate the pollution from the direct application of nutrients and pesticides to intensive row crops from the more regional impacts of pollutants transported through the atmosphere. As the boundaries of the small springsheds become well constrained by additional tracing, they will serve as a small simple groundwater springshed to help calibrate the baseflow discharge per unit area relationships (Quinlan \& Ray, 1995). Such small springsheds also offer convenient locations for student field exercises and research. The new springsheds are shown in Figures 2, 4, 5 and 6.

Table 1 lists the names, spring numbers and areas of the springsheds discussed in this paper. The first five springsheds in column one are modified from Alexander et al. (1995). The names of springsheds "5. Mahoods" and " 11 . Canfield" have been changed from those listed in Alexander et al. (1995) to reflect the local usage.

Table 1. Springsheds, springs and areas.

\begin{tabular}{|l|c|c|}
\hline Springshed Name & $\begin{array}{c}\text { Spring } \\
\text { Numbers }\end{array}$ & $\begin{array}{c}\text { Mapped Area } \\
\text { (hectares) }\end{array}$ \\
\hline 5. Mahoods & A47 & 630 \\
\hline 6. Forlorn River & A2, A3 & 2508 \\
\hline 11. Canfield & A33, A34 & 2862 \\
\hline 13. Stagecoach & A4 & 1707 \\
\hline 25. Meyers & A875 & 88 \\
\hline 26. Rainy & A31 & 165 \\
\hline 27. Burr Oak & A29 & 115 \\
\hline 28. Dry Dam & A94 & 94 \\
\hline
\end{tabular}


the springs are a shortened version of the springs' full numbers, which, for example, have the form MN23:A0047 for "A47". The "Mapped Areas" are subject to future revision and refinement.

Dye travel times were generally in the 1.5 to $4.5-\mathrm{km} /$ day range. This is consistent with previous tracing work done in the county. Since fluorescent dyes are conservative tracing agents, this is a reasonably accurate range of groundwater flow time through the karst conduit system in the Spillville-Galena karst.

Meyers Springshed: The Meyers Springshed, named after the family that owns much of its surface, lies just to the west of Forestville State Park (Figure 2). The discharge point is spring MN23:A0875 on the SBRR. Prior to this project it was assumed that groundwater recharge from much of this area drained north to Forestville Creek and was part of the Forlorn River springshed. The tracing found that the subsurface drainage flowed south to the SBRR to a previously unmapped spring. As a result of the additional funding for dye tracing in the SBRR, the Meyers Springshed is one of the best-defined springsheds in Minnesota with traces from six different sinkholes feeding the Meyers Springshed Spring (A875).

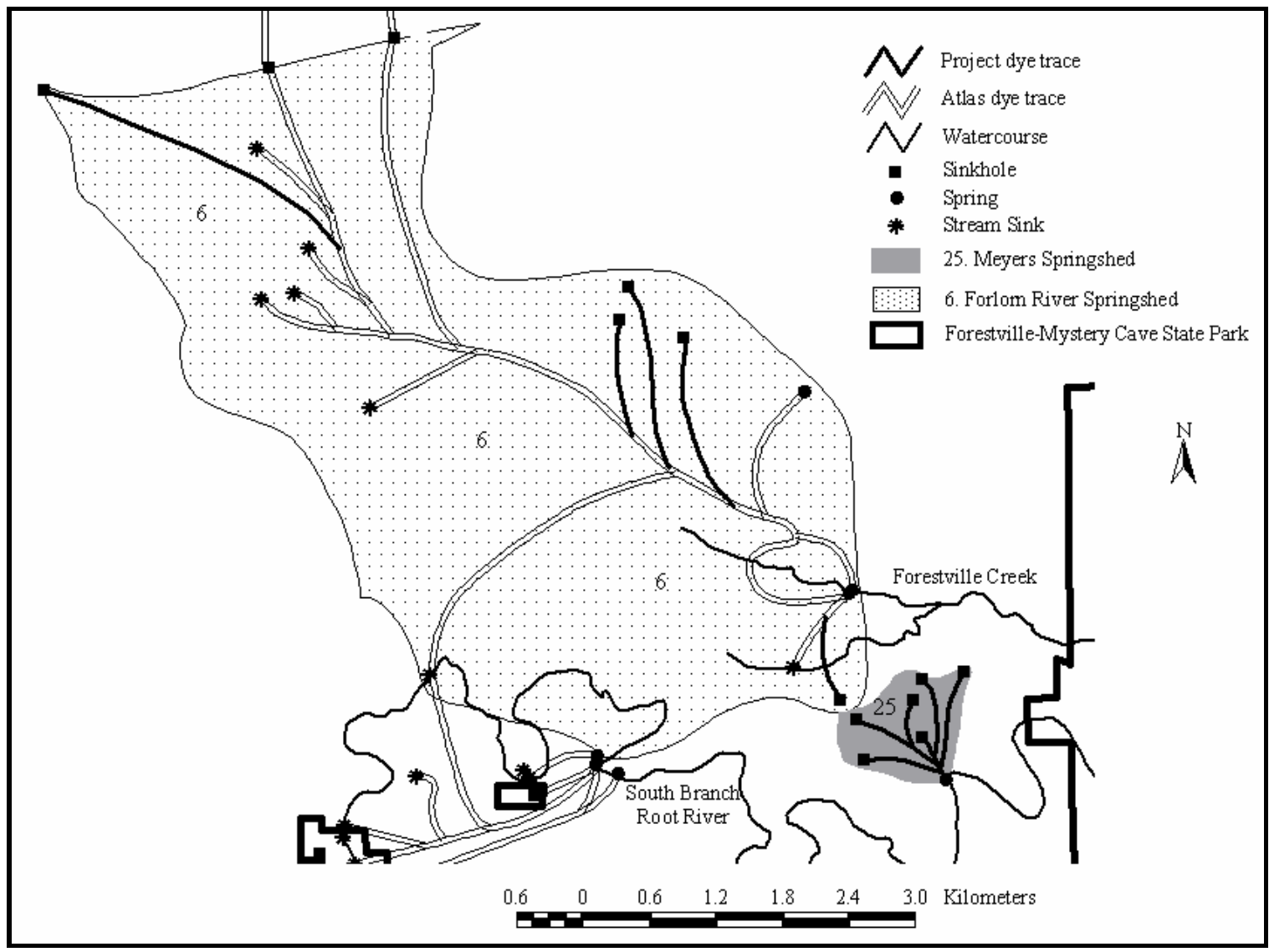

Figure 2. Meyers Springshed location map.

Figure 2 illustrates the relative size of the Meyers Springshed with the adjacent Forlorn River Springshed whose resurgence in Moth (A2) and Grabau (A3) Springs forms the headwaters of Forestville Creek. At 88 hectares the Meyers Springshed is equivalent to about $4 \%$ of the size of the Forlorn River springshed that feeds A2 and A3 (Table 1).

The traces that defined the Meyers Springshed were monitored with a combination of charcoal detectors and direct water samples collected by auto samplers. During the initial trace, the auto samplers were located on the wrong spring and it was data from the charcoal detectors in the SBRR that led us to the previously unmapped spring. 
The breakthrough curves of dye traces in these systems typically yield an asymmetric breakthrough curve, which may have two or more apparently different sloped "tails". The main peak is assumed to be due to turbulent mixing in the conduits but there is little agreement on the mechanisms responsible for the tails. Everts et al. (1989) demonstrated that fluorescent tracer dyes and conservative anions such as bromide would differentially adsorb when they moved through approximately two meters of soil. If two or more tracers with differential adsorption properties were injected simultaneously at the same point and if their breakthrough curves were measurably different, that difference might shed light on the source of the tails.

In October 1999, as part of a class exercise, a quadruple trace was conducted from sinkhole D3882 in the Meyers Springshed to spring A875, the Meyers Springshed resurgence spring. Four tracers (Rhodamine WT, eosin, uranine $\mathrm{C}$ and bromide) were mixed together and injected simultaneously. Spring A875 has a well developed spring run in alluvium that lends itself to the installation of a temporary weir. A weir was installed and documented a steady spring flow of 18.4 liter/sec during the duration of the trace. Figure 3 shows the breakthrough curves for the four tracers.

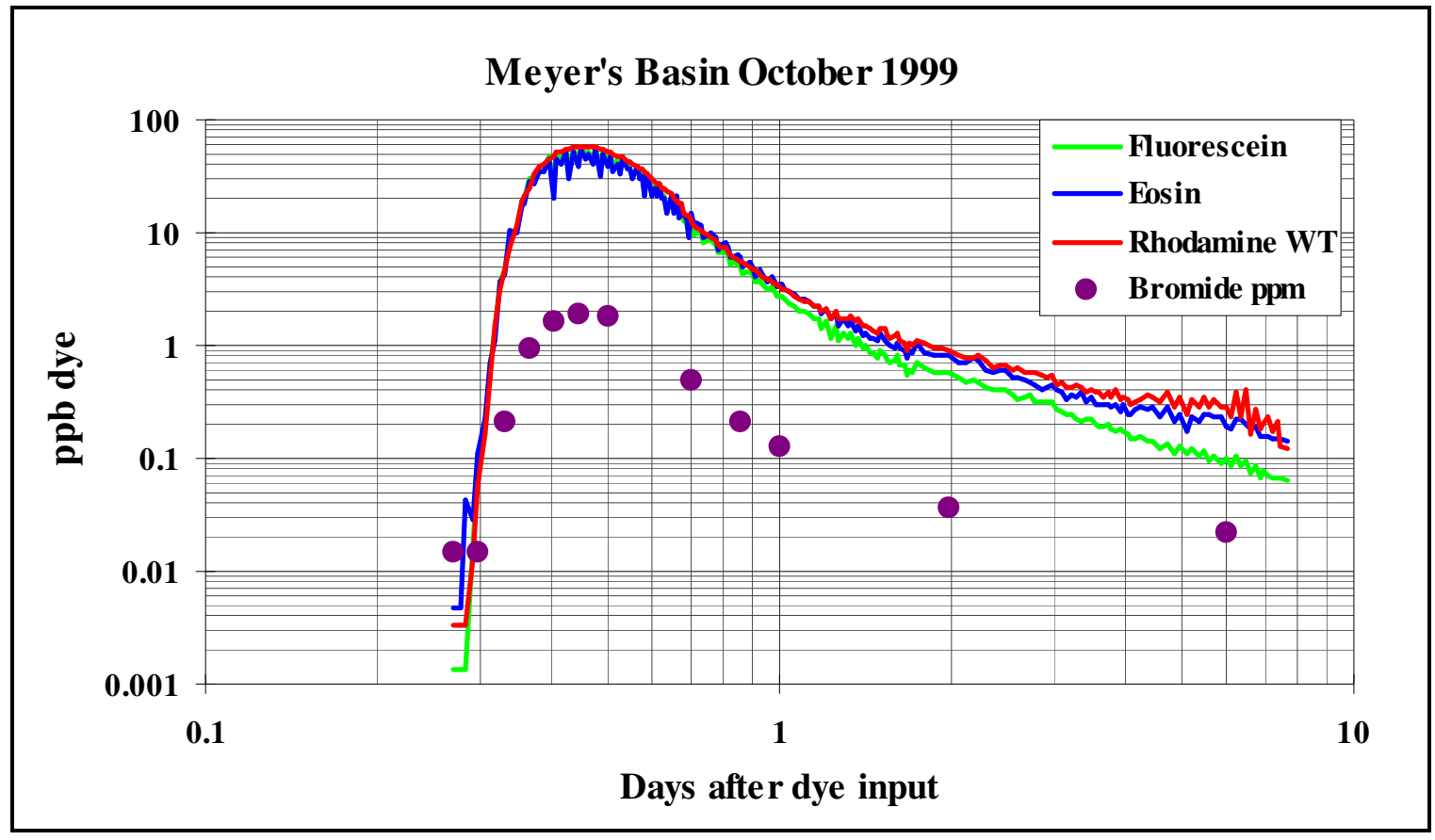

Figure 3. Breakthrough curves from a quadruple tracer test in the Meyers Springshed.

The four breakthrough curves are similar (Note that the $\mathrm{Br}$ data are in ppm rather than ppb reflecting its higher detection limit and analytical cost. The latter limited the number of $\mathrm{Br}$ analyses that could be made.) The uranine $\mathrm{C}$ tailed off the fastest of the three fluorescent dyes. Eosin was in the middle and Rhodamine WT tailed off the slowest. The differences, however, are small and need to be replicated. The integration of these concentration data with the constant flow rate gave the following dye recoveries: $35 \%$ for eosin, $47 \%$ of the uranine C, and $77 \%$ for Rhodamine WT. These recoveries are opposite of what was expected from the sorption properties of the tracers. Further interpretation awaits replication of this trend in other traces.

East of Canfield Creek, southeast of Forestville State Park: The Alexander et al. (1995) Fillmore County Springshed map depicts a large, probably compound springshed (11. Canfield) feeding Canfield Big Springs (A33, A34), the headwater springs of Canfield Creek in Forestville State Park. Traces were run on the east side of that springshed to better determine its boundaries with neighboring springsheds. The results of those traces are shown in Figure 4. These new traces documented that the northern part of the area actually flowed to Rainy Spring (A31), a tributary to Canfield Creek downstream from the headwaters springs. This springshed is "Rainy Springshed (26.)". Two of the traces discharged at 
both sets of springs. These two traces delineate the boundary between springsheds 11 and 26 . The mapped sinkholes north of the Rainy Springshed suggest that there are additional small springsheds to the north.

Three of the traces went to springs in other surface drainages that are not part of the project area. These three traces begin to delineate two springsheds, 27. Burr Oak that resurges at A29 and 28. Dry Dam that resurges at A94. These new springshed boundaries are as yet poorly defined and there are still gaps between the known springsheds. There are numerous sinkholes in the untraced area and additional future traces will clarify the limits of the springsheds.

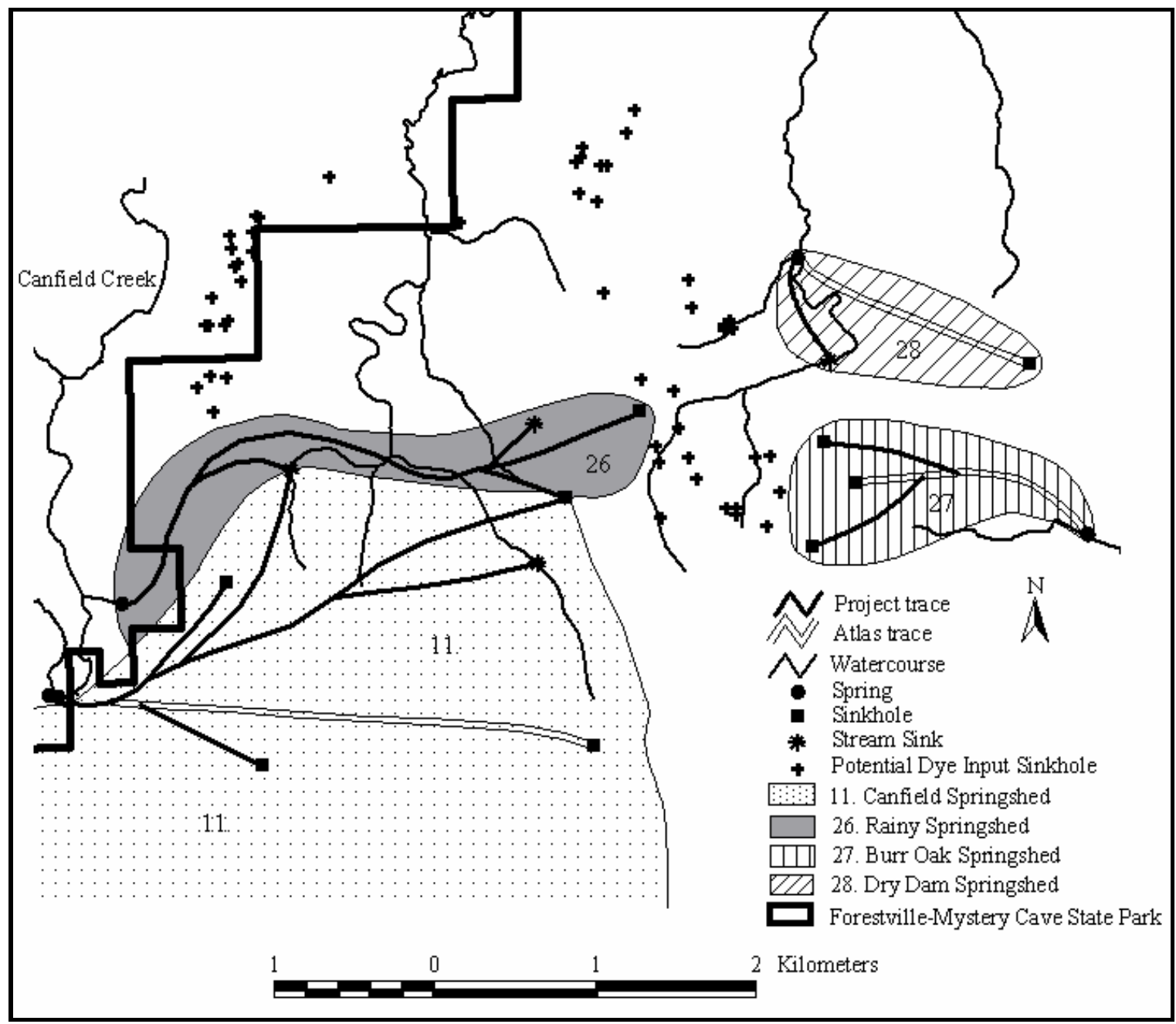

Figure 4. East of Canfield Creek, Rainy, Burr Oak and Dry Dam Springsheds.

Northwest of Forestville State Park, the northeast boundary of the Forlorn River Springshed: The 1995 map has a large untraced area forming the northeast side of springshed 6. Forlorn River, the southeast side of the springshed 5. Mahoods, the south and west sides of springshed 13. Stagecoach (the headwaters of Watson Creek), and the northwest and northern sides of Forestville State Park (Figure 5). Several traces were attempted from sinkholes in this area. An unusually large fraction of those traces were "lost", i.e. not detected anywhere. While some progress was made, there is still a large gap on the map between these three springsheds. Since there are sinkholes and stream sinks between them, future dye traces are a possibility.

A major state highway crosses both the Stagecoach and the Forlorn River Springsheds; in addition, a large petroleum tank complex is located in the western end of the Forlorn River surface springshed. That complex dispatches many large tanker trucks of petroleum products per day. Dye tracing 
here provides a critical component for emergency response to spills and other releases and future traces to further refine springshed boundaries remain a high priority.

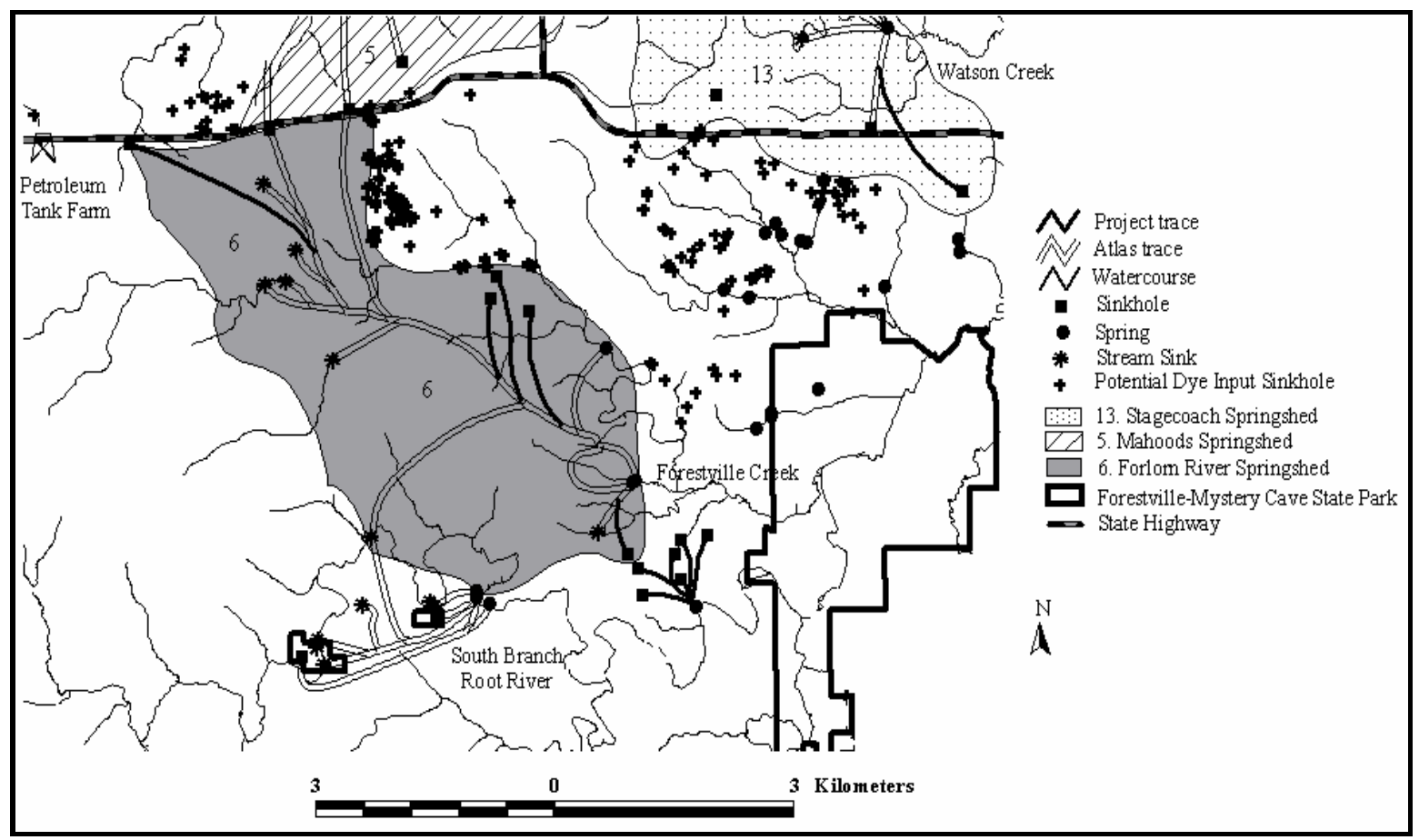

Figure 5. The 6. Forlorn River, 5. Mahoods and 13. Stagecoach Springsheds.

\section{Conclusion}

This work represents an important step forward in our knowledge of the karst groundwater flow systems in the South Branch Root River watershed. As a result, more accurate monitoring can be done of local springs, conservation practices can be targeted for specific springsheds and better land use management decisions can be made. This work also demonstrates the effect of scale on a karst springshed mapping effort. The work for the 1995 map was done at a county scale as we tried to delineate the springsheds of the largest known Spillville-Galena springs. The Forestville springsheds work has been confined to a much smaller area (about $20 \%$ of the county); at this scale the smaller springsheds are more easily identified.

There is, however, more work to be done. The boundaries between many of the springsheds are still not adequately defined and more tracing is needed. The existing traces were done under the hydrologic conditions that prevailed at the time of the trace. These traces, particularly those recovered in multiple springs, should be replicated under different hydrologic conditions. With additional tracing around the Forestville Park area, a more complete dye-tracing map for the area can be produced. This map could then be used to better manage the springsheds feeding the springs that produce the high-quality trout streams, provide groundwater flow information for emergency response to spill events, and to educate and inform citizens about how water moves through the landscape in the area.

\section{Acknowledgments}

This work was funded by the Clean Water Partnership/319 program of the Minnesota Pollution Control Agency and by the Minnesota Dept. of Natural Resources-Division of Waters. Many people from within the study area helped us to accomplish this work. Donna Rasmussen, Fillmore County Water Planning Coordinator provided leadership and funding. Ernie Meyer III invited us on to his property to dye trace. Mark White of Forestville State Park provided assistance and equipment. Joe Ray of the Kentucky Division of Water provided valuable review and comment. 


\section{References}

Alexander, E. Calvin, Jr., Green, Jeffrey A., Alexander, Scott C. and Spong, Ronald C. (1995) Springsheds. Plate 9 in Geological Atlas of Fillmore County, Minnesota, County Atlas Series, Atlas C-8, Part B, Minn. Dept. of Natural Resources, St. Paul.

Alexander, Scott C. (2005) Spectral deconvolution of natural organics and man-made fluorescent dyes. This volume.

Everts, C.J., Kanwar, R.S., Alexander, E.C., Jr. and Alexander, S.C. (1989) Comparison of tracer mobilities under laboratory and field conditions. J. Environ. Qual., v. 18, n. 4, p. 491-498.

Green, Jeffrey A., Alexander, E.C. Jr, and Alexander, S.C. (2005) "The Springsheds of Forestville" http://files.dnr.state.mn.us/waters/groundwater_section/mapping/cga/c08_fillmore/pdf_files/forest villespringsheds2005.pdf

Quinlan, J.F., and Ray, J.A., 1995, Normalized base-flow discharge of groundwater springsheds: A useful parameter for estimating recharge area of spring and for recognizing drainage anomalies in karst terranes: in Karst Geohazards, B.F. Beck, ed., Balkema, Rotterdam, p. 149-164. 